\title{
Morphological variation of wild peppers (Capsicum spp.) from the state of Tabasco, Mexico
}

\author{
Julio César Velázquez-Ventura1, César Márquez-Quiroz¹, Efraín de la Cruz-Lázaro1*, \\ Rodolfo Osorio-Osorio', Pablo Preciado-Rangel²
}

${ }^{1}$ Universidad Juárez Autónoma de Tabasco, División Académica de Ciencias Agropecuarias. Km 25 de la carretera fed. 195, tramo Villahermosa-Teapa. Ra. La Huasteca $2^{\circ}$ secc. CP. 86298. Centro, Tabasco. México, ${ }^{2}$ División de Estudios de Posgrado e Investigación, Instituto Tecnológico de Torreón, Carretera Torreón-San Pedro, Torreón, Coahuila, México

\section{A B S T R A C T}

\begin{abstract}
The pepper (Capsicum spp.) is one of the most important vegetables in Mexico. The aim of this study was to collect wild peppers and characterize in situ their morphological diversity. From January to November 2015, field trips were made to 54 locations in 15 municipalities in the state of Tabasco, Mexico; 131 collections were obtained in which a total of 23 plant, flower and fruit variables were evaluated. With the mean values of the variables, principal component (PC) and cluster analyses were performed. The first three PCs explained $65.2 \%$ of total morphological variability, with the variables fruit length, fruit shape, fruit width, leaf width, leaf length, plant height and branch density providing a greater explanation for the diversity. Cluster analysis grouped the 131 collections into two groups, one formed by the morphotypes 'Amashito', 'Garbanzo' and 'Ojo de cangrejo', with characteristics of $C$. annuum var. Glabriusculum, and the second group with the morphotype 'Pico de paloma' with characteristics of the species $C$. frutescens L. It is concluded that the wild peppers of the State of Tabasco have morphological diversity, which must be preserved as a genetic resource of interest.
\end{abstract}

Keywords: Cluster analysis; Genetic resources; Morphological diversity; Morphotypes; Principal component analysis

\section{INTRODUCTION}

The pepper (Capsicum spp.) is one of the most important vegetables in Mexico and the world. The genus Capsicum is composed of about 37 species, of which only Capsicum annum L, C. chinense Jacq., C. frutescens L., C. baccatum L. and C. pubescens Ruíz \& Pav. were domesticated (Bosland and Votava, 2012; Zhang et al., 2016). The species C. annum L., which stands out in economic importance and cultivated area, has its center of diversity and domestication in Mexico (Hayano-Kanashiro et al., 2016).

In Mexico, wild peppers of the species $C$. annuum, C. frutescens, C. ciliatum and C. lanceolatum (Castañón-Nájera et al., 2008; Vera-Guzmán et al., 2011) can be found from sea level to over 2000 meters above sea level (Hernández-Verdugo et al., 2012; Kraft et al., 2013). Studies on wild peppers indicate high levels of morphological variation between and within species and populations (Hernández-Verdugo et al., 2015; Hayano-Kanashiro et al.,
2016), with variation in characters related to phenology, plant, flower and fruit shape (Bosland and Votava, 2012). The most important for morphological description are those that have less environmental influence, such as fruit, leaves and stem (Castañón-Nájera et al., 2008), which can be used to satisfactorily discriminate between species of wild peppers (Hernández-Verdugo et al., 2012).

In southeastern Mexico and in particular in the state of Tabasco, wild pepper populations of the species C. annuum var. glabriusculum and C. frutescens, which show morphological and genetic variability, can be found (Castañón-Nájera et al., 2008). This is a valuable resource that is at risk of being lost due to adverse factors such as habitat destruction, hurricanes, floods and droughts (Narez-Jiménez et al., 2014). Therefore, it is necessary to collect and characterize the diversity of wild peppers in order to know their characteristics and to conserve this resource for the breeding of cultivated peppers (Hayano-Kanashiro et al., 2016). Due to the above, the aim

\footnotetext{
${ }^{*}$ Corresponding author:

Efraín de la Cruz-Lázaro, Universidad Juárez Autónoma de Tabasco, División Académica de Ciencias Agropecuarias. Km 25 de la carretera fed. 195, tramo Villahermosa-Teapa. Ra. La Huasteca $2^{\circ}$ secc. CP. 86298. Centro, Tabasco. México. Phone: +48 628486262. E-mail: efrain.delacruz@ujat.mx
}

Received: 05 May 2017; Accepted: 06 February 2018 
of this work was to characterize in situ the morphological diversity of the different wild pepper morphotypes found in the state of Tabasco, Mexico.

\section{MATERIALS AND METHODS}

The work was carried out in the state of Tabasco, located between $18^{\circ} 39^{\prime} 03^{\prime \prime}$ and $17^{\circ} 15^{\prime} 03^{\prime \prime} \mathrm{NL}$, and $90^{\circ} 59^{\prime} 15^{\prime \prime}$ and $94^{\circ} 07^{\prime} 48^{\prime \prime}$ WL, on the coastal plain of the Gulf of Mexico, with an area of $24738 \mathrm{~km}^{2}$. The predominant climate types in the state are warm humid with abundant rainfall throughout the year $(A f)$ in $19.64 \%$ of the area, warm humid with abundant rainfall in summer $(A m)$ in $75.97 \%$ of the area and warm sub-humid with rainfall in summer $\mathrm{A}(w)$ in $4.39 \%$ of the area. Annual precipitation is between 2500 and $3000 \mathrm{~mm}$ and the average annual temperature is $26.6^{\circ} \mathrm{C}$ (INEGI, 2015).

The exploration sites were selected based on studies carried out by Castañón-Nájera et al. (2008) and Narez-Jiménez et al. (2014), and information on collection dates and sites provided by the wild pepper sellers in the markets of the explored municipalities. The collections were carried out from January to November 2015 through walks along paths and visits to orchards, paddocks, and banana and cocoa ecosystems in 54 localities in the municipalities of Balancán, Cárdenas, Centla, Centro, Comalcalco, Cunduacán, Emiliano Zapata, Huimanguillo, Jalapa, Jalpa de Méndez, Macuspana, Nacajuca, Tacotalpa, Teapa and Tenosique in the state of Tabasco, Mexico.

In the plants or groups of plants collected, 23 morphological plant, flower and fruit variables were evaluated (Table 1) on the basis of the descriptors for Capsicum proposed by IPGRI-CATIE-AVRDC, (1995) and the Technical guide for varietal description of pepper (Capsicum annumm) of SAGARPA-SNICS, (2014). Based on fruit and flower variables, the species to which the collections belong was identified (Andrews, 1995; Hernández-Verdugo et al., 1999; Bosland and Votava, 2012). In-situ morphological characterization was performed for 131 plant collections or groups of plants, at elevations from sea level up to 495 meters above sea level. For each collection, coordinates were recorded with GPS (Garmin eTrex ${ }^{\circledR}$ ) to locate the collection sites (Fig. 1). From each plant or group of plants, all the ripe fruits were taken, stored in paper bags and transferred to the Agricultural Sciences Research Center at the Juárez Autonomous University of Tabasco (Universidad Juárez. Autónoma de Tabasco), where they were left to dry at room temperature, after which the number of seeds per fruit was counted.

With the means of each variable, a first principal component analysis (PCA) was carried out; it included the 131 collections and the 23 variables, which were standardized to $\mu=0$ and $\sigma^{2}=1$. This first analysis allowed determining the 16 most important variables for describing the variability of the collections, with which a second PCA was carried out. In both analyzes, PC estimation was performed with the correlation matrix, so that the variables involved in the analysis were equally important (Johnson and Wichern, 2007). The significance of the eigenvalues and eigenvectors was determined by Keizer's rule (1960). After a cluster analysis was performed from the squared Euclidean distance matrix with Ward's minimum variance method, the cut height was decided based on the cubic clustering criterion and the pseudo- $\mathrm{t}^{2}$ and pseudo-F statistics (Johnson and Wichern, 2007). All statistical analyses were performed using the SAS 9.4 program (SAS, 2013).

\section{RESULTS AND DISCUSSION}

A total of 131 wild pepper collections were obtained from the morphotypes 'Amashito', 'Ojo de cangrejo', 'Garbanzo' and 'Pico de paloma' (Fig. 2). The collections of the morphotypes 'Pico de paloma' (45.8\%) and 'Garbanzo' $(30.5 \%)$ account for a higher proportion of the total, while the morphotypes 'Amashito' (18.3\%) and 'Ojo de cangrejo' $(5.4 \%)$ are found to a lesser extent. The lower proportion of 'Ojo de cangrejo' and 'Amashito' is due to the fact that they are the wild peppers preferred for local consumption and sale (Narez-Jiménez et al., 2014).

The first principal component analysis (PCA) with the 23 variables showed that the first three PCs explained 45.1\% of total morphological variability. In this regard, CastañónNájera et al. (2008) indicate that by eliminating the variables that contribute little or nothing to the explanation of PC1, PCA is improved. By performing PCA with the 16 selected variables, the first three PCs explained $65.2 \%$ of total variability (Table 2), with the first five PCs having significant values according to Keiser (1960).

PC1 explained $35.8 \%$ of total morphological variation, which was positively determined by the variables fruit shape, fruit shape at the juncture with the pedicel and fruit apex shape, and negatively by the variables fruit length and fruit weight. This indicates that the component was determined by fruit variables, which is consistent with previous studies on the morphological diversity of wild peppers, in which it was reported that the first component was explained by fruit variables (Narez-Jiménez et al., 2014). PC2 explained $17.1 \%$ of total morphological variability, with the variables stem diameter, plant height, plant width, leaf color, leaf length, leaf width, fruit length, fruit width and number of seeds per fruit being the variables that contributed most to 
Table 1: Plant, flower and fruit descriptors

\begin{tabular}{|c|c|c|}
\hline & Variable & Measurement method \\
\hline \multirow[t]{10}{*}{ Plant } & 1) Stem diameter & $\begin{array}{l}\text { In millimeters }(\mathrm{mm}) \text { with a digital Vernier caliper graduated } \\
\text { in } \mathrm{mm} \text {. }\end{array}$ \\
\hline & 2) Plant height & $\begin{array}{l}\text { In centimeters }(\mathrm{cm}) \text { with a measuring tape graduated in } \\
\mathrm{cm} \text {. }\end{array}$ \\
\hline & 3) Plant width & $\begin{array}{l}\text { In centimeters }(\mathrm{cm}) \text { with a measuring tape graduated in } \\
\mathrm{cm} \text {. }\end{array}$ \\
\hline & 4) Stem pubescence & $3=$ sparse, $5=$ intermediate and $7=$ dense. \\
\hline & 5) Plant growth habit & $3=$ prostrate, 5 =intermediate, $7=$ erect and $9=$ other (specify). \\
\hline & 6) Branch density & $3=$ sparse, $5=$ intermediate, $7=$ dense. \\
\hline & 7) Leaf color & $1=$ yellow $2=$ light green, $3=$ green, $4=$ dark green. \\
\hline & 8) Leaf shape & 1 =deltoid, $2=0$ val, $3=$ lanceolate. \\
\hline & 9) Leaf length & $\begin{array}{l}\text { In millimeters }(\mathrm{mm}) \text { with a digital Vernier caliper graduated } \\
\text { in } \mathrm{mm} \text {. }\end{array}$ \\
\hline & 10 Leaf width & $\begin{array}{l}\text { In millimeters }(\mathrm{mm}) \text { with a digital Vernier caliper graduated } \\
\text { in } \mathrm{mm} \text {. }\end{array}$ \\
\hline \multirow[t]{4}{*}{ Flower } & 11) Number of flowers per axil & $\begin{array}{l}1=\text { one, } 2=\text { two, } 3=\text { three or more, } 4=\text { many flowers, but each } \\
\text { in an individual axil, } 5=\text { other. }\end{array}$ \\
\hline & 12) Flower position & $3=$ slope, $5=$ intermediate, $7=$ =erect. \\
\hline & 13) Corolla color & 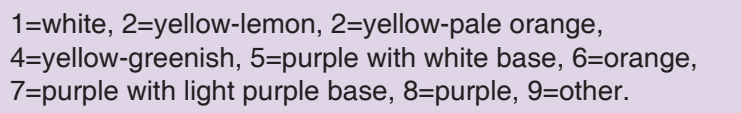 \\
\hline & 14) Corolla shape & $1=$ round, $2=$ campanulate and $3=$ other (indicate). \\
\hline \multirow[t]{9}{*}{ Fruit } & 15) Color of fruit in mature state & $\begin{array}{l}1=\text { white, } 2=\text { yellow-lemon, } 3=\text { yellow-pale orange, } \\
4=\text { yellow-orange, } 5=\text { pale orange, } 6=\text { orange, } 7=\text { light red, } \\
8=\text { red, } 9=\text { dark red, } 10=\text { purple, } 11=\text { brown, } 12=\text { black, } \\
13=\text { other. }\end{array}$ \\
\hline & 16) Fruit length & $\begin{array}{l}\text { In millimeters }(\mathrm{mm}) \text { with a digital Vernier caliper graduated } \\
\text { in } \mathrm{mm} \text {. }\end{array}$ \\
\hline & 17) Fruit width & $\begin{array}{l}\text { In millimeters }(\mathrm{mm}) \text { with a digital Vernier caliper graduated } \\
\text { in } \mathrm{mm} \text {. }\end{array}$ \\
\hline & 18) Fruit weight & In grams (gr), with a digital scale. \\
\hline & 19) Fruit pedicel length & $\begin{array}{l}\text { In millimeters }(\mathrm{mm}) \text { with a digital Vernier caliper graduated } \\
\text { in } \mathrm{mm} \text {. }\end{array}$ \\
\hline & 20) Fruit shape & $\begin{array}{l}1=\text { elongated, } 2=\text { almost round, } 3=\text { triangular, } 4=\text { bell-shaped, } \\
5=\text { bell-shaped and block, } 6=\text { other (indicate). }\end{array}$ \\
\hline & 21) Fruit shape at junction with the pedicel & $1=$ acute, $2=$ obtuse, $3=$ truncated, $4=$ chordate, $5=$ lobed. \\
\hline & 22) Fruit apex shape & $\begin{array}{l}1=\text { pointy, } 2=\text { blunt, } 3=\text { sunken, } 4=\text { sunken and pointy, } \\
5=\text { other. }\end{array}$ \\
\hline & 23) Number of seeds per fruit & Count. \\
\hline
\end{tabular}

the explanation of the component. PC3 explained 12.3\% of total morphological variability, being determined in greater proportion by the variables stem diameter, plant height, plant width and branch density, whereas PC4 explained $9.5 \%$ of total morphological variability, and was explained by the variables branch density, fruit width, fruit weight and number of seeds per fruit. Regarding PC5, it explained $7.5 \%$ of total variability, being determined by the variables stem diameter, plant growth habit and fruit width. The results indicate that all plant structures showed variability, which is useful for collection discrimination. In this regard, Castañón-Najera et al. (2008) indicate that the morphological variability in wild peppers is explained to a greater degree by fruit and plant variables.

The distribution of the wild pepper morphotypes by means of the first two principal components, PC1 and
PC2 (Fig. 3), gave rise to two groups, the first with the morphotypes 'Amashito', 'Garbanzo' and 'Ojo de cangrejo', while the second group was formed with the morphotype 'Pico de paloma'. The collections of the first group were located in the positive quadrant of PC1 and the positive and negative quadrants of PC2 (Fig. 3). The first group was formed by 71 collections that have fruits of lower weight, a round shape and a blunt or sunken apex, while the second group was formed by 60 collections, which are located in the negative quadrant of PC1 and are distributed in the positive and negative quadrant of PC2; this group was formed by collections that have fruits of greater weight, an elongated shape and a pointy fruit apex. In this regard, Castañón-Nájera et al. (2008) and Narez-Jiménez et al. (2014) report that the state of Tabasco has wild pepper morphotypes characterized by round and pointy fruits. 


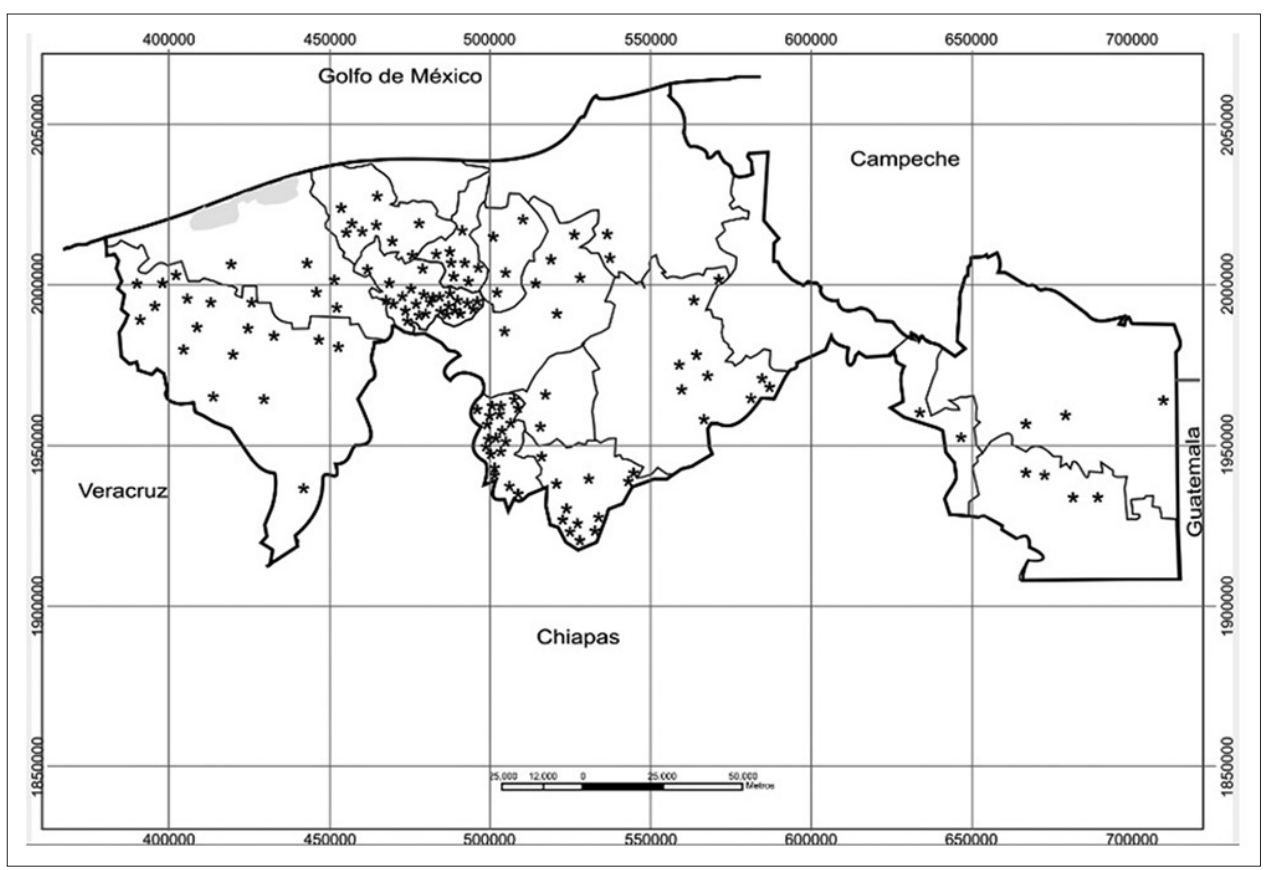

Fig 1. Geographic location of the localities where the 131 collections of wild peppers were made in the state of Tabasco, Mexico.

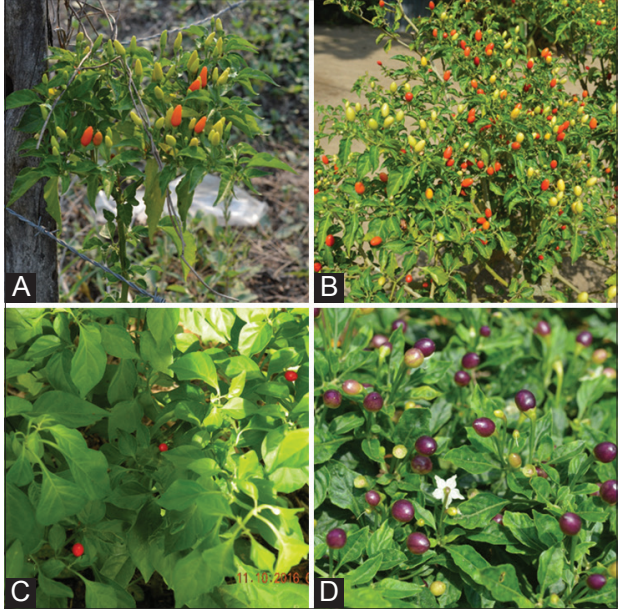

Fig 2. Wild pepper morphotypes. A = 'Pico de paloma', B = 'Garbanzo', $\mathrm{C}=$ 'Amashito' and $\mathrm{D}=$ 'Ojo de cangrejo'.

The fruits of the morphotypes 'Amashito', 'Garbanzo' and 'Ojo de cangrejo' are mainly characterized by having roundshaped fruits, a characteristics that according to Andrews (1995), Mogkolporn and Taylor (2011), Bosland and Votava (2012), Kraft et al. (2013) and Hayano-Kanashiro et al. (2016) is one of the main traits presented by the species Capsicum annuum var. glabriusculum, while the morphotype 'Pico de paloma' has elongated, pointyshaped fruits, a characteristic that according to Andrews (1995), Hernández-Verdugo et al. (1999) and Kraft et al. (2013) is shared by the wild fruits of the species Capsicum frutescens L. On this, Hernández-Verdugo et al., (1999), Castañón-Nájera et al. (2008) and Narez-Jiménez et al. (2014) reported the presence in the state of Tabasco of wild populations of the species C. annum var. glabriusculum and C. frutescens L., with morphological and genetic variability.

Cluster analysis enabled grouping the 131 collections into two morphologically different groups (Fig. 4), by taking as reference a semi-partial $R^{2}$ distance of 0.10 units. Group 1 was formed by collections of the morphotypes 'Amashito', 'Ojo de cangrejo' and 'Garbanzo', which by their flower and fruit characteristics belong to the species C. annum var. glabriusculum, which is the wild form of the cultivated pepper C. annum var annum L. (Andrews, 1995; Hernández-Verdugo et al., 1999). This group is characterized by having plants with an average height of $1.13 \mathrm{~m}$, fruit weight of $0.30 \mathrm{~g}$, fruit length of $9.2 \mathrm{~mm}$, fruit width of $6.8 \mathrm{~mm}$ and 16 seeds per fruit, values that are within the ranges reported for the species by Hernández-Verdugo et al. (1999) and Narez-Jiménez et al. (2014). As for group 2, it was formed by 60 collections of the morphotype 'Pico de paloma', which belongs to C. frutescens $\mathrm{L}$., with average fruit weight of $0.40 \mathrm{~g}$, length of $16.2 \mathrm{~mm}$, width of $5.7 \mathrm{~mm}, 17$ seeds per fruit and average plant height of $1.18 \mathrm{~m}$, values within the range reported for wild fruits of C. frutescens L. (Hernández-Verdugo et al., 1999; Castañón-Nájera et al., 2008).

\section{CONCLUSIONS}

The morphological variability found in the 131 collections of wild peppers from the state of Tabasco is grouped into the species C. annum var. glabriusculum ('Amashito', 'Garbanzo' and 'Ojo de cangrejo') and C. frutescens L. ('Pico 


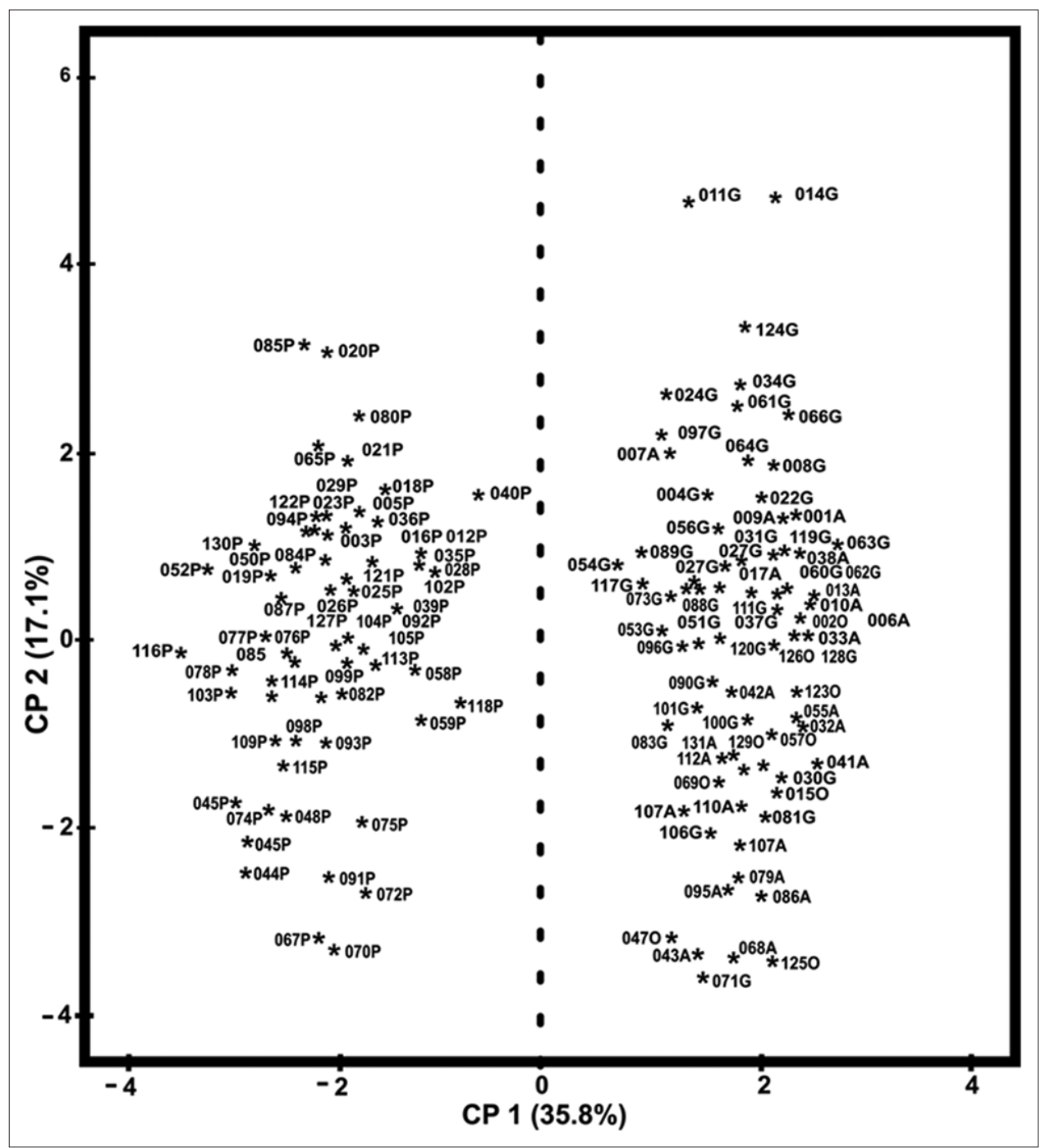

Fig 3. Distribution of the 131 collections of Capsicum spp., as a function of $\mathrm{PC} 1$ and $\mathrm{PC} 2$ obtained with the correlation matrix. $\mathrm{P}=$ pico paloma, $\mathrm{G}=$ garbanzo, $\mathrm{A}=$ amashito and $\mathrm{O}=$ ojo de cangrejo.

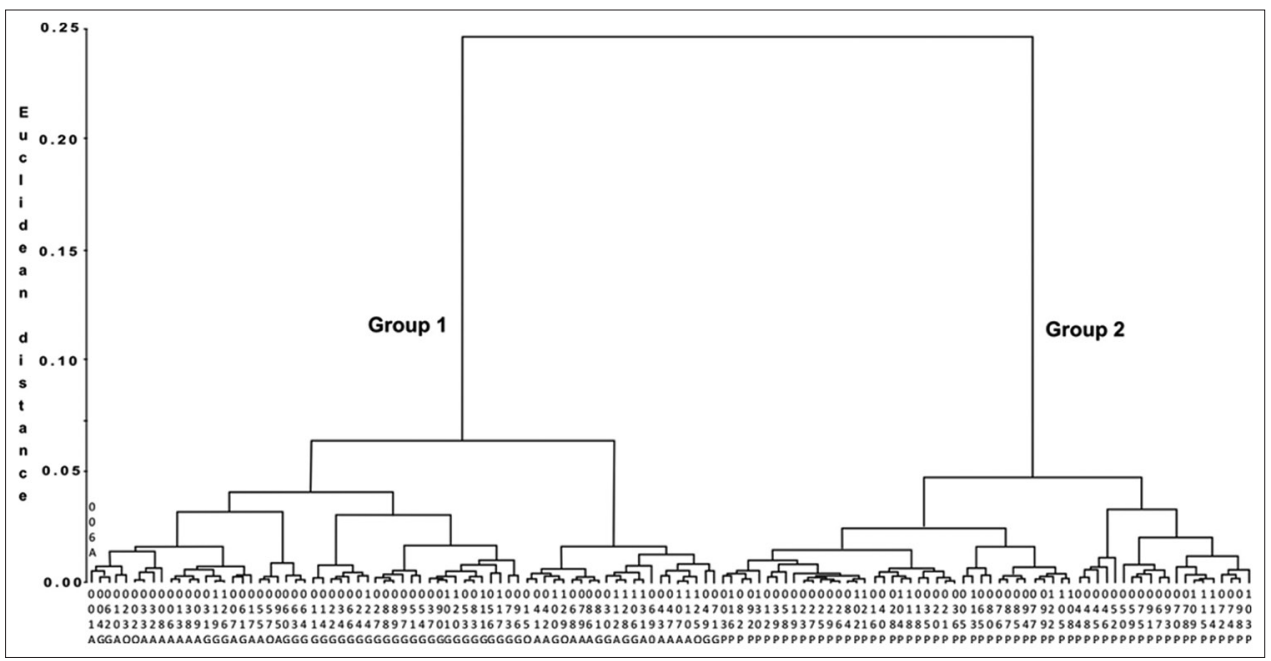

Fig 4. Ward's clustering of 131 pepper (C. annuum var. glabriusculum and $C$. frutescens) collections where A = 'Amashito', $\mathrm{O}=$ 'Ojo de cangrejo', $\mathrm{G}=$ 'Garbanzo' and $\mathrm{P}=$ 'Pico de paloma'. Group $1=\mathrm{C}$. annuum var. glabriusculum, Group $2=\mathrm{C}$. frutescens. 
Table 2: Eigenvectors and eigenvalues of the PCs with variables of the highest descriptive value

\begin{tabular}{lccccc} 
Variable & PC1 & PC2 & PC3 & PC4 & PC5 \\
\hline Stem diameter & 0.107 & $0.285^{*}$ & $0.337^{*}$ & $-0.252^{*}$ & $0.219^{*}$ \\
Plant height & -0.050 & $0.219^{*}$ & $0.448^{*}$ & -0.175 & 0.042 \\
Plant width & 0.007 & $0.217^{*}$ & $0.526^{*}$ & $-0.210^{*}$ & -0.048 \\
Plant growth habit & 0.001 & 0.055 & -0.135 & -0.175 & $0.755^{*}$ \\
Branch density & -0.076 & -0.104 & $0.493^{*}$ & $0.205^{*}$ & -0.050 \\
Leaf color & 0.173 & $0.252^{*}$ & -0.098 & $-0.220^{*}$ & $-0.358^{*}$ \\
Leaf length & 0.047 & $0.492^{*}$ & $-0.219^{*}$ & -0.158 & -0.100 \\
Leaf width & 0.052 & $0.476^{*}$ & $-0.244^{*}$ & -0.106 & 0.010 \\
Color of fruit in mature state & -0.025 & 0.166 & 0.030 & 0.162 & $-0.399^{*}$ \\
Fruit length & $-0.410^{*}$ & $0.202^{*}$ & -0.029 & 0.064 & 0.011 \\
Fruit width & 0.171 & $0.351^{*}$ & -0.053 & $0.421^{*}$ & $0.204^{*}$ \\
Fruit weight & $-0.223^{*}$ & 0.172 & 0.127 & $0.476^{*}$ & 0.183 \\
Fruit shape & $0.472^{*}$ & -0.023 & 0.057 & 0.156 & 0.025 \\
Fruit shape at junction with the pedicel & $0.477^{*}$ & -0.012 & 0.062 & 0.146 & 0.026 \\
Fruit apex shape & $0.477^{*}$ & -0.012 & 0.062 & 0.146 & 0.026 \\
Number of seeds per fruit & -0.137 & $0.238^{*}$ & -0.002 & $0.452^{*}$ & -0.043 \\
Eigenvalue & 4.123 & 2.731 & 1.964 & 1.526 & 0.193 \\
Variation explained & 0.358 & 0.171 & 0.123 & 0.652 & 0.095 \\
Cumulative variation & 0.358 & 0.529 & & 0.747 \\
\hline
\end{tabular}

${ }^{*}$ Significant according to Keiser (1960).

de paloma'), indicating that these peppers constitute a genetic resource that must be conserved as a reservoir of genes with the potential to solve agricultural problems. The species $C$. annum var. glabriusculum and $C$. frutescens $\mathrm{L}$. are present in all the municipalities included in the study, with the morphotypes 'Pico de paloma' and 'Garbanzo' being found to a greater extent than the morphotypes 'Amashito' and 'Ojo de cangrejo'.

\section{ACKNOWLEDGMENTS}

The authors thank the Juárez Autonomous University of Tabasco's Research Promotion Program for the partial support given to the project and the thesis scholarship awarded to the first author.

\section{Authors' contributions}

J.C.V.V.: carried out the fieldwork, data collection and the first draft of the paper; C.M.Q.: participated in the development of the research and revised the article; E.C.L.: participated in the development of the research, data analysis, and the writing and revision of the paper; R.O.O.: participated in the development of the research and in the revision of the article; P. P. R.: participated in the data analysis and discussion.

\section{REFERENCES}

Andrews, J. 1995. Peppers: The Domesticated Capsicum. New Edition. University of Texas Press, Austin, Texas. USA.

Bosland, P.W. and E. J. Votava. 2012. Peppers: Vegetable and Spice Capsicums. $2^{\text {nd }}$ Edition. Cabi Publishing. London, UK.
Castañón-Najera, G., L. Latournerie-Moreno, L, Mendoza-Elos, A. Vargas-López and H. Cárdenas-Morales. 2008. Colección y caracterización de chile (Capsicum spp.) en Tabasco, México. Phyton. Rev. Int. Bot. Exp. 77: 189-202.

Hayano-Kanashiro, C., N. Gámez-Meza and L. A. Medina-Juárez. 2016. Wild pepper Capsicum annuum L. var. Glabriusculum: Taxonomy, plant morphology, distribution, genetic diversity, genome sequencing and phytochemical compounds. Crop Sci. 56(1): 1-11.

Hernández-Verdugo, S., R. A. González-Sánchez, F. Porras, S. Parra-Terraza, A. Valdez-Ortiz, A. Pacheco-Olvera and R. G. López-España. 2015. Plasticidad fenotípica de poblaciones de chile silvestre (Capsicum annuum var. Glabriusculum) en respuesta a disponibilidad de luz. Bot. Sci. 93(2): 1-10.

Hernández-Verdugo, S., F. Porras, A. Pacheco-Olvera, R. G. López-España, M. Villarreal-Romero, S. Parra-Terraza and E. T. Osuna. 2012. Caracterización y variación ecogeográfica de poblaciones de chile (Capsicum annuum var. Glabriusculum) silvestre del noroeste de México. Polibotánica. 33(1):175-191.

Hernández-Verdugo, S., P. Dávila-Aranda and K. Oyama. 1999. Síntesis del conocimiento taxonómico, origen y domesticación del género Capsicum. Bol. Soc. Bot. Méx. 64: 65-84.

Instituto Nacional de Estadística y Geografía (INEGI). 2015. Anuario Estadístico y Geográfico de Tabasco 2015. INEGI, México.

IPGRI-CATIE-AVRDC. 1995. Descriptores para Capsicum (Capsicum spp.). Instituto Internacional de Recursos Fitogenéticos, Italia; Centro Asiático para el Desarrollo y la Investigación Relativos a los Vegetales, Taipei, Taiwan y Centro Agronómico Tropical de Investigación y Enseñanza, Turrialba, Costa Rica.

Johnson, D.E. and D. W. Wichern. 2007. Applied Multivariate Statistical Analysis. Pearson Education Inc., USA, p. 773.

Keiser, H.F. 1960. The application of electronic computers to factor analysis. Educ. Psychol. Meas. 20(1): 141-151.

Kraft, K. H., J. J. Luna-Ruíz and P. Gepts. 2013. A new collection of wild populations of Capsicum in Mexico and the southern United States. Genet. Resour. Crop. Evol. 60: 225-232.

Mogkolporn, O. and P. V. J. Taylor. 2011. Capsicum. In: K. Ch. 
(Ed.), Wild Crop Relatives: Genomic and Breeding Resources Vegetables. Springer, USA, p. 43-57.

Narez-Jiménez, C. A., E. de la Cruz-Lázaro, A. Gómez-Vázquez, G. Castañón-Nájera, A. Cruz-Hernández and C. MárquezQuiroz. 2014. La diversidad morfológica in situ de chiles silvestres (Capsicum spp.) de Tabasco, México. Rev. Fitotec. Mex. 37(3): 209-215.

SAGARPA-SNICS. 2014. Guía técnica para la descripción variedad de chile (Capsicum annuum L.). SAGARPA, SNICS. Tlanepantla, Edo. de México.

SAS. 2013. Base SAS $® 9.4$ Procedures Guide Statistical Procedures. $2^{\text {nd }}$ ed. SAS Institute Inc., Cary, NC. p. 550.

Vera-Guzmán, A. M., J. L. Chávez-Servia, J. C. Carrillo-Rodríguez and G. M. López. 2011. Phytochemical evaluation of wild and cultivated pepper (Capsicum annuum L. and C. pubescens Ruiz \& Pav.) from Oaxaca, Mexico. Chil. J. Agric. Res. 71(4): 578-585.

Zhang, X. M., Z. H. Zhang, X. Z. GU, S.L. Mao, X. X. Li, J. Chadoeuf, A. Palloix, L. H. Wang, and B. X. Zhang. 2016. Genetic diversity of pepper (Capsicum spp.) germplasm resources in China reflects selection for cultivar types and spatial distribution. J. Integr. Agric. 15(9): 1991-2001. 